\title{
FBI attaches strings to its DNA database
}

Washington. Researchers are criticizing the US Federal Bureau of Investigation (FBI), which controls one of the largest databases of human DNA samples, for refusing to allow an independent researcher to use the data unless FBI scientists are permitted to review his work and to be listed as coauthors. Although the FBI says that the ruling is not agency policy, officials admit that they have not yet decided how to handle the issue of data access. A recent report by the US National Academy of Science (NAS) strongly recommends that data be made freely available to all researchers.

In a letter dated 12 May to Seymour Geisser, a University of Minnesota statistician, James Kearney, the head of the FBI forensic science research centre, refused to permit the use of the data unless Geisser agreed to give an FBI scientist the right to approve the paper. Kearney says that the FBI is "not quite sure of [Geisser's] intent" in seeking to analyse the data, pointing out that Geisser has testified for the defence in DNA fingerprinting cases. Kearney acknowledged that the FBI has provided the data to other researchers (he named three scientists, at least two of whom have testified for the prosecution in DNA fingerprinting cases), but said they were picked because they were experts in population genetics.

Kearney agreed to provide the data only on the condition that Geisser analyse them in collaboration with Bruce Budowle, an FBI scientist, and that Budowle should have final approval of the paper. Geisser rejected that arrangement as "obviously unacceptable". He has since revised his paper - on statistical techniques as they apply to population data - to use an artificial dataset.

Geisser had asked the FBI for permission to use the data on the advice of Charles Epstein, editor of the American Journal of Human Genetics, which is considering Geisser's paper. Although the data had been released as part of a court case, Epstein recommended that Geisser seek explicit approval from the FBI for their inclusion in the paper. But he decided to drop the FBI data entirely after the FBI refused to grant permission and after Geisser said he was unwilling to let the agency researchers "censor" the paper.

"It's an unfortunate situation when such data are not made available, presumably because they [the FBI] might not be in agreement with the outcome", says Epstein. "By trying to extract that kind of promise [of coauthorship] they are showing that they are not truly interested in the free flow of information."

Earlier this year, the same paper triggered a dispute with the FBI after federal prosecutors demanded that Geisser turn over a draft of the manuscript and any comments from reviewers. Because this request came 15 minutes after Epstein faxed the comments to Geisser, the case prompted allegations of conspiracy (see Nature 355, 753; 1992), although most of the parties now say that the timing was an unfortunate coincidence.

The data have been used by the FBI in several court cases to support convictions based on DNA fingerprinting and have been the basis of published articles by several pro-DNA-fingerprinting researchers. According to Victor McKusick, chairman of the panel that produced the NAS report, the data are generally considered to be in the public domain.

McKusick says the FBI position of re-

"We are willing to approve your
use of FBI population data with
certain provislons....The FBI data
may be used only in a joint collabo-
ration with Dr Budowle....The use
of the data is restricted to this one
paper. All parties (i.e., authors)
must agree to the entire contents
of a final manuscript prior to
submission to a journal. Any
changes whatsoever in the manu-
script must be agreed upon by all
collaborating parties."
- FBI letter to Seymour Geisser

quiring coauthorship on Geisser's paper "is contrary to the spirit" of the NAS report, which explicitly calls for open access to population data. Noting that "presenting scientific conclusions in a criminal court is at least as serious as presenting scientific conclusions in an academic paper", the report concludes that "the data underlying [those conclusions] must be freely available....If scientific evidence is not yet ready for both scientific scrutiny and re-evaluation by others, it is not ready for court."

John Hicks, assistant director of the FBI's laboratory division, says that the letter from Kearney does not restrict access to the data. Although the FBI specifically warned Geisser that use of the data was contingent on FBI coauthorship, he says, "we can't stop Geisser from using them without our permission." It would be a "misinterpretation" to read the letter as a prohibition on use without complying with the FBI demands, he says; Kearney was "simply asking that a professional courtesy [coauthorship in exchange for use of data] be extended".

Hicks says that FBI policy on data access is "still evolving". The agency is following a recommendation from the NAS report to form an advisory committee to recommend data policies. The issue, however, is an "awkward" one, Hicks says — "privacy experts are concerned about people [using the data to] draw possibly adverse inferences" about the behaviour of population subgroups. "In general we agree with open and free access, but I'm a little bit concerned that if we do it, someone may misuse it."

But McKusick calls that argument a "smokescreen" to restrict use of the data. Because the particular DNA regions used in the database do not correspond with expressed traits, "nothing in the data identifies whether the individual is a rapist or a Supreme Court justice". Concern about privacy need not be a barrier to the free and open use of the data, he says.

Christopher Anderson

\section{Germany plans university reform}

Munich. Responding to a call for reform of the university system in Germany, the Ministry of Education and Science last week announced a six-point plan to speed students through their courses and improve university facilities, particularly for scientists.

Last month, the regional governments of Germany's 16 states spoke out for the first time in support of their financially strapped universities (see Nature 357, 349; 1992). In response, the education minister, Rainer Ortleb, has recommended that:

Universities should require students to graduate within four years instead of the current average of eight years.

More places should be provided at universities specializing in applied science research. Ortleb hopes to increase the proportion of students attending these vocational universities from 28 to 40 per cent.

The government should invest DM1,600DM2,000 million (US $\$ 1,000-\$ 1,300$ million) next year in building projects, and vocational universities should be given priority.

More science graduates should be encouraged to enter the university system to be trained to replace the steadily ageing population of professors, 50 per cent of whom will have reached retirement age by 2005 . Ortleb has recommended that spending on university research should remain constant in the next few years, despite Germany's recession, to give scientists the opportunity for suitable training.

The federal government will discuss the recommendations and their budgetary implications this summer. A final decision, expected by the end of the year, will also depend on approval of the universities principals and trade unions. Allson Abbott 